\title{
Mitigating Effect of Vitamin-E on Copper Sulphate- Induced Toxicity in African Catfish (Clarias gariepinus)
}

\author{
O. I. Azeez and S. F. Braimah
}

\begin{abstract}
Copper sulphate is widely used not only in livestock production especially in the treatment of foot rot in small ruminants but also in aquaculture as algaecide and an ectoparasiticide in hatcheries. Meanwhile, it is a common environmental contaminant of water bodies, with carcinogenic, mutagenic and teratogenic effects in humans and animals. The present study was therefore designed to evaluate the toxic effects of copper sulphate and the protective activities of vitamin $\mathbf{E}$ on haematological and biochemical parameters as well as oxidative stress status in the African catfish (Clarias gariepinus)

Sixty juvenile African catfish with an average weight of $120 \mathrm{~g}$ were used for the study. They were assigned into six groups (AF) consisting of ten fish per group. Group A served as the control group and was fed with normal pelletized fish feed only, group B was fed with Vitamin E-supplemented feed only, groups $C$ and $D$ were exposed to copper sulphate $(20 \mathrm{mg} / \mathrm{L}$ and $5 \mathrm{mg} / \mathrm{L}$ ) respectively, plus normal pelletized fish feed while groups $E$ and $F$ were exposed to copper sulphate $(20 \mathrm{mg} / \mathrm{L}$ and $5 \mathrm{mg} / \mathrm{L})$, respectively, plus Vitamin E-supplemented feed $(240 \mathrm{mg} / \mathrm{kg}$ feed). Blood samples were collected for haematology and plasma biochemical parameters while gills, liver and kidney samples were collected for evaluation markers of oxidative stress. Exposure to copper sulphate led to a significant decrease in PCV, RBC, Hb concentration, MCV, MCH and total WBC when compared with the unexposed control and those fed with vitamin E-supplemented feed. Furthermore, exposure to copper sulphate caused liver and kidney damages and cell impairment by increasing plasma ALT, AST and ALP activities. It also led to increased oxidative stress as the concentrations of antioxidant endogenous enzymes - GPx, GST and GSH were depleted while potentiating lipid peroxidation and hydroxyl radical generation. The changes in the haematological, biochemical and antioxidant parameters were restored in the fish fed with vitamin E-supplemented feed.

In conclusion, the study showed that exposure to copper sulphate is toxic to African catfish, causing anaemia and liver damage through free radical generation and depletion of antioxidant defence system. Vitamin - $\mathbf{E}$ supplementation is therefore recommended during the use of $\mathrm{CuSO}_{4}$ in aquaculture. Release of the compound to the environment must however be avoided at all cost.
\end{abstract}

Index Terms - Copper sulphate, Haematology, Oxidative stress, Vitamin E.

\section{INTRODUCTION}

Contamination of aquatic environments by heavy metals and related compounds through natural and anthropogenic sources has been reported to be a significant threat to public health [1]. It is also known to cause oxidative stress in aquatic organisms leading to numerous physiological dysfunctions in fish [2]. The toxicity of metals becomes

Published on August 31, 2020.

O. I. Azeez, University of Ibadan, Nigeria.

(corresponding e-mail: odunayoazeez ${ }^{@}$ gmail.com)

S. F. Braimah, University of Ibadan, Nigeria. more dangerous when present in high concentrations due to their stability, long half-life and bioaccumulation in the environment [3]. The concentration of copper in pond water remains at a toxic level at least 50 hours after single treatment and can also inhibit the fish growth [4]. Bioaccumulation in the body of organisms, leads to disruption of biological food chain and eventually causing deleterious health effects in the consumers of aquatic products including humans [5], making it important to assess and quantify associated risks of environmental pollution and degradation to aquatic organisms. Heavy metals such as copper affect the vital physiological functions through increased reactive oxygen species (ROS) and free radical generation upon exposure [6].

It was previously reported that heavy metals affect the central nervous function leading to mental disorder, damage the blood constituents and may damage the lungs, liver, kidneys and other vital organs promoting several disease conditions [7]. More so, repeated long-term contact with some of these heavy metals or their compounds may even damage nucleic acids, cause mutation, mimic hormones thereby disrupting the endocrine and reproductive system and eventually lead to cancer [8]. Copper sulphate is released into water as a result of agricultural run-off, natural weathering of soil and discharge from industries [9]. Copper sulphate is extremely toxic to fish and other aquatic organisms, but this toxicity decreases with increasing $\mathrm{pH}$ and total alkalinity concentrations [10].

Despite its toxicity, copper sulphate is used for the control of mortality caused by external bacteria, external parasites, and fungus on finfish and finfish eggs in hatcheries [11]. In aquaculture practices, copper sulphate has also been widely used to control algae and other pathogens [12]. The use of copper sulphate in the control of algae and other parasites in water requires high concentrations which are recommended at $50 \mu \mathrm{g} / \mathrm{L}$ minimal dose [13]. However, this practice can pose acute risks to various organisms resulting from direct water application and run-offs from fields adjacent to water bodies [14].

Vitamin E, a fat-soluble vitamin, plays an important role in the maintenance of the normal metabolic processes and physiological functions of aquatic animals [15]. For example, Vitamin $\mathrm{E}$ is involved in immune response by potentiating phagocyte system and immunostimulants such as granulocyte macrophage colony-stimulating factor [16]. One of the main physiological functions of Vitamin $E$ is to protect membranes from oxidative damage by mopping up free radicals so as to terminate lipid peroxidation [17, 18]. The antioxidant role of vitamin $\mathrm{E}$ is based on the presence of a hydroxyl group in its phenolic group on the chromanol ring that can donate a hydrogen atom and, in this way; 
neutralize a great variety of free radicals including reactive oxygen species [19].

The African catfish (Clarias gariepinus) is one of the most important fish in Africa suitable for consumption and commercial purpose. It has recently been adopted as a model animal in the field of biology, vertebrate embryology, and environmental toxicology due to its well documented biology [20], [21] and responses to changes in environmental factors and toxicants.

Although, copper-containing compounds have been subjects of importance in toxicology research, there exists a lack of appropriate scientific data on their effects on Clarias gariepinus and possibly the mitigating effects of vitamin $\mathrm{E}$ in feed. Therefore, this study examines the toxicity of this compounds and how its toxicity can be ameliorated using Vitamin E.

\section{MATERIALS AND METHODS}

\section{A. Drugs and chemicals}

Analytical grades of copper sulphate (Sigma-Aldrich) and Vitamin $\mathrm{E}$ were procured from local agents in Ibadan, Nigeria.

\section{B. Experimental animals}

Sixty (60) apparently healthy unsexed juvenile African catfish (C. gariepinus), with average weight of $120 \mathrm{~g}$ procured from the University of Ibadan Aquaculture Laboratory were used for this study. From our observation, the Aquaculture Unit was devoid of any industrial effluent or any other sources of pollution that could affect the biochemical responses of the control fish. The fish were inspected for general fitness and were allowed to acclimatize for 3 weeks in plastic bowls of 80 litres $(80 \mathrm{~L})$ capacity during which time they were fed twice daily. All experimental protocols were in compliance with University of Ibadan ethics committee on research in animals as well as internationally accepted guidelines for laboratory animal use and care. The protocol was approved the University of Ibadan Animal Care Use, Research and ethics Committee with ethical clearance number UI-ACUREC/19/0089.

\section{Determination of physico-chemical parameters of the water.}

The physico-chemical parameters of the water consisting of the temperature, dissolved oxygen (D.O), hydrogen ion concentration $(\mathrm{pH})$ and conductivity were determined before the commencement of the study using Sension M156+ Portable multimeter.

\section{Experimental feed}

Two types of feed were used for this experiment: a pure commercial feed and a vitamin E-supplemented feed. The commercial pelletized feed (Ecofloat) contains 38\% crude protein. The vitamin E-supplemented feed was prepared by mixing the commercial feed with vitamin E $(240 \mathrm{mg} / \mathrm{kg}$ of feed) and then re-pelletized using a pelletizing machine.

\section{E. Experimental Protocol}

After three weeks of acclimatization during which the fish were all fed with the same feed, the fish with similar initial body weight were randomly assigned into 6 groups (A-F) at the commencement of the treatment. Group A served as the control was fed with normal pelletized fish feed only, group B was fed with Vitamin E-supplemented feed only, group C was exposed to sub-lethal dose of copper sulphate $(20 \mathrm{mg} / \mathrm{L})$ [22] with slight modification, plus normal pelletized fish feed, group D was exposed to low dose of copper sulphate $(5 \mathrm{mg} / \mathrm{L})$ [22] plus normal pelletized fish feed, group E was administered with copper sulphate $(20 \mathrm{mg} / \mathrm{L})$ plus Vitamin E-supplemented feed $(240 \mathrm{mg} / \mathrm{kg}$ diet $)$ while group F was given to copper sulphate $(5 \mathrm{mg} / \mathrm{L})$ plus Vitamin $\mathrm{E}$ supplemented feed $(240 \mathrm{mg} / \mathrm{kg}$ diet $)$. The fish in each group were fed at $5 \%$ body weight twice a day until apparent satiation for fourteen days for fourteen (14) days.

\section{F. Evaluation of growth parameters}

All fish were weighed at the commencement and the end of the experiment (14 days), to calculate weight gain (WG) and feed conversion ratio (FCR). The amount of feed consumed was recorded throughout the period of the experiment to determine the feed intake (FI). Growth performance and feed utilization were assessed in terms of weight gain (WG) and feed conversion ratio (FCR) using the following formula:

$$
\begin{gathered}
\mathrm{WG}(\mathrm{g})=\mathrm{W}_{2}-\mathrm{W}_{1} \\
\mathrm{FCR}=\underline{\mathrm{FI}}
\end{gathered}
$$

Where,

$\mathrm{W}_{2}=$ final body weight,

$\mathrm{W}_{1}=$ initial body weight,

$\mathrm{W}=$ body weight,

$\mathrm{FI}=$ feed intake,

$\mathrm{WG}=$ weight gain

\section{G. Determination of haematological parameters}

After 14 days, blood samples were collected from the ventral vein of each fish into heparinized tubes. From the samples collected, the Packed Cell Volume (PCV) was determined by microhaematocrit method, red Blood Cells (RBC) and White Blood Cells (WBC) haemocytometer method using the improved Neubauer slide [23]. Haemoglobin concentration ( $\mathrm{Hb}$ ) was determined by cyanmethaemoglobin method while the Mean Corpuscular Volume (MCV), Mean Corpuscular Haemoglobin (MCH) and Mean Corpuscular Haemoglobin Concentration (MCHC) were calculated from the PCV, RBC and $\mathrm{Hb}$ values [23], erythrocyte osmotic fragility was determined according to the method described by Azeez et al. [24].

\section{H. Determination of plasma biochemical parameters}

Blood samples were centrifuged at $4000 \mathrm{rev} / \mathrm{min}$ for 10 min to obtain the plasma. From the plasma, urea and creatinine were determined spectrophotometerically according to the methods of Coloumbe and Farreau, and Taussky respectively [25], [26]. Total protein and albumin in plasma samples were also determined by the methods described by Bradford and Doumas et al., [27], [28] while plasma globulin was calculated as the difference between total protein and albumin. Alkaline phosphatase activity was determined by the method of Bessey [29] while activities of ALT and AST were determined by the method of Reitman 
and Frankel [30]. The plasma concentrations of total cholesterol (TC), high-density lipoprotein cholesterol (HDLC), low-density lipoprotein cholesterol (LDL-C) and triglyceride (TG) were determined by enzymatic colorimetric method using the following Roche kits according the manufacturer's protocol.

\section{Determination of markers of oxidative stress}

Lipid peroxidation was quantified as malondialdehyde (MDA) according to the method described by Farombi et al. [31], reduced glutathione (GSH) concentrations by the method of Jollow et al. [32] while Glutathione-S-transferase (GST) activity was determined according to the method described by Farombi et al. [33]. Hydrogen peroxide generation was evaluated according to the method of Wolff [34]. Protein concentration was determined by Biuret method as described by Gornal et al. [35]. Glutathione peroxidase activity was measured according to the method described by Rotruck et al. [36].

\section{J. Statistical analysis}

All values are expressed as mean \pm S.D. "One-way Analysis of Variance" (ANOVA) with Tukey's post-hoc test was performed to compare the data between groups using GraphPad Prism version 7.0 with probability value of $\mathrm{P}<$ 0.05 considered statistically significant.

\section{RESULTS}

\section{A. The physico-chemical parameters of the water used}

From the results in Table 1, the physico-chemical parameters of the water used were within the accepted international EPA standard. For example, the $\mathrm{pH}$ of the water was neutral at $7.33 \pm 0.84$, which corresponds to the average acceptable international EPA standard. The dissolved oxygen was also high enough for survival of the fish at $5.71 \pm 0.88$, which was higher than the acceptable international EPA standard.

TABLE 1: THE PHYSICO-CHEMICAL PARAMETERS OF THE WATER USED

\begin{tabular}{ccc}
\hline Parameters & Values & EPA standard \\
\hline Temperature $\left({ }^{\circ} \mathrm{C}\right)$ & $27.34 \pm 2.67$ & 25 \\
$\mathrm{pH}$ & $7.33 \pm 0.84$ & $\geq 6 \leq 9$ \\
Dissolved oxygen & $5.71 \pm 0.88$ & $\geq 5$ \\
$(\mathrm{mg} / \mathrm{L})$ & $215.53 \pm 13.01$ & $200-1000$ \\
Conductivity $(\mu \mathrm{S} / \mathrm{cm})$ &
\end{tabular}

EPA - Environmental Protection Agency.

\section{B. Growth performance and feed conversion}

Figure 1 shows the growth performance and feed utilization parameters of the African catfish exposed to copper sulphate. After 14 days of exposure, there was a reduction in weight in the fish exposed to sub-lethal dose
$(20 \mathrm{mg} / \mathrm{L})$ of $\mathrm{CuSO}_{4}$ whereas those fish in all the other groups showed increases in weight. The feed conversion ratio and efficiency was highest in group B that was fed vitamin E-supplemented feed alone, closely followed by group $\mathrm{F}$ that was exposed to copper sulphate $(5 \mathrm{mg} / \mathrm{L})$ plus vitamin E-supplemented feed while group $\mathrm{C}$ did not show any evidence of feed conversion but lost weight instead with an FCR of -2.4 .

Table 2 shows the weight of liver and heart compared to the body weight of African catfish in acute copper sulphate exposure. The percentage weight of liver to body ratio of fish exposed to different concentrations of copper sulphate (20 $\mathrm{mg} / \mathrm{L}$ and $5 \mathrm{mg} / \mathrm{L}$ ) relative to body ratio was significantly higher than those of the control group and the groups fed with vitamin E-supplemented feed at $\mathrm{p}<0.05$.

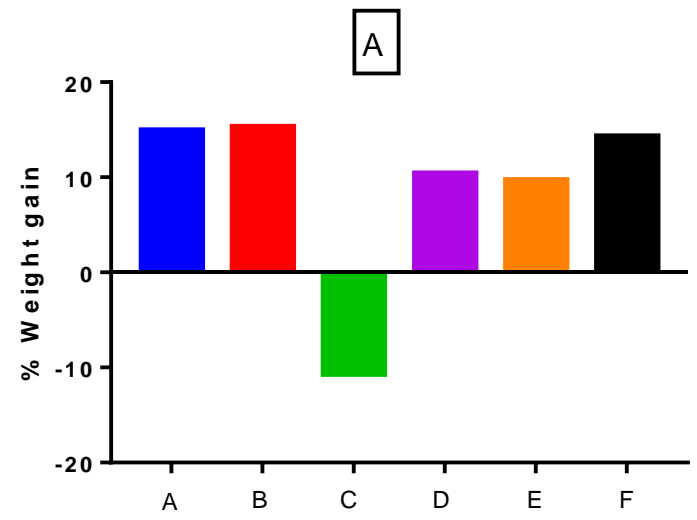

B

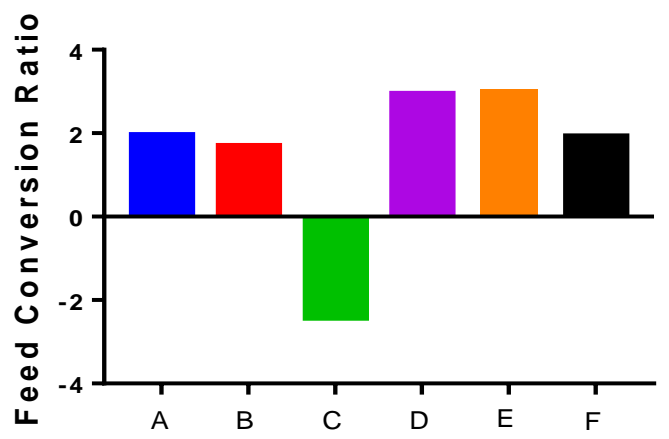

Fig. 1: Effect of acute copper sulphate toxicity on percentage weight gain (A) and feed conversion ratio (B) in African catfish (Clarias gariepinus) as modulated by vitamin $\mathrm{E}$

A = Control, $\mathrm{B}=$ Vitamin E-supplemented feed, $\mathrm{C}=$ Copper sulphate $(20 \mathrm{mg} / \mathrm{L})$ alone, $\mathrm{D}=$ Copper sulphate $(5 \mathrm{mg} / \mathrm{L})$ alone, $\mathrm{E}=$ Copper sulphate $(20 \mathrm{mg} / \mathrm{L})$ alone + Vitamin E-supplemented feed, F = Copper sulphate $(5 \mathrm{mg} / \mathrm{L})$ alone + Vitamin E-supplemented feed, $\mathrm{n}=$ number of fish.

TABLE 2: EFFECT OF ACUTE COPPER SULPHATE TOXICITY ON ORGAN-BODY WEIGHT RATIO IN AFRICAN CATFISH (CLARIA GARIEPINUS) AS MODULATED BY

\begin{tabular}{|c|c|c|c|c|c|c|}
\hline Parameters & $\mathbf{A}$ & B & $\mathrm{C}$ & D & $\mathbf{E}$ & $\mathbf{F}$ \\
\hline BW (g) & $186.23 \pm 12.55^{\mathrm{a}}$ & $192.13 \pm 14.86^{\text {be }}$ & $141.19 \pm 13.64^{\text {abcde }}$ & $163.20 \pm 11.76$ & $165.46 \pm 12.38^{c}$ & $174.90 \pm 9.37^{\mathrm{d}}$ \\
\hline LW (g) & $2.31 \pm 0.18$ & $2.11 \pm 0.23$ & $2.46 \pm 0.15$ & $2.66 \pm 0.20$ & $2.19 \pm 0.17$ & $2.29 \pm 0.62$ \\
\hline L-B weight (\%) & $1.24 \pm 0.04^{\mathrm{ab}}$ & $1.10 \pm 0.05^{\mathrm{cd}}$ & $1.74 \pm 0.23^{\text {acef }}$ & $1.63 \pm 0.12^{\text {bd }}$ & $1.33 \pm 0.09^{\mathrm{e}}$ & $1.31 \pm 0.07^{\mathbf{f}}$ \\
\hline HW (g) & $0.16 \pm 0.05$ & $0.15 \pm 0.04$ & $0.14 \pm 0.02$ & $0.14 \pm 0.02$ & $0.17 \pm 0.04$ & $0.14 \pm 0.01$ \\
\hline H-B weight $(\%)$ & $0.08 \pm 0.02$ & $0.09 \pm 0.01$ & $0.10 \pm 0.02$ & $0.08 \pm 0.01$ & $0.10 \pm 0.02$ & $0.10 \pm 0.00$ \\
\hline
\end{tabular}

Data are presented as mean $\pm \mathrm{SD}$. Where $\mathrm{BW}=$ bodyweight $(\mathrm{g}), \mathrm{LW}=$ liver weight $(\mathrm{g}), \mathrm{L}-\mathrm{B}=$ percentage liver/body ratio $(\%), \mathrm{HW}=$ heart weight $(\mathrm{g})$, $\mathrm{H}-\mathrm{B}=$ percentage heart/body ratio. Values with the same superscript alphabets along the same row are significantly different at $\mathrm{P}<0.05$. $\mathrm{A}=\mathrm{Control}, \mathrm{B}=$ Vitamin E-supplemented feed, $\mathrm{C}=$ Copper sulphate $(20 \mathrm{mg} / \mathrm{L})$ alone, $\mathrm{D}=$ Copper sulphate $(5 \mathrm{mg} / \mathrm{L})$ alone, $\mathrm{E}=\mathrm{Copper}$ sulphate $(20 \mathrm{mg} / \mathrm{L})$ alone + Vitamin E-supplemented feed, F = Copper sulphate $(5 \mathrm{mg} / \mathrm{L})$ alone + Vitamin E-supplemented feed, $\mathrm{n}=$ number of fish. 


\section{Haematological parameters}

As shown in Table 3, exposure of $C$. gariepinus to copper sulphate caused significant decreases $(\mathrm{P}<0.05)$ in $\mathrm{PCV}$, $\mathrm{RBC}, \mathrm{Hb}, \mathrm{MCV}$ and $\mathrm{MCHC}$ values when compared with the control group, whereas in the groups co-treated with copper sulphate and vitamin E, haematological parameters were similar to those in the control and significantly higher than the groups exposed to copper sulphate alone. However, $\mathrm{MCH}$ values showed no significant difference across the groups. The total WBCs, lymphocyte and neutrophil count decreased significantly $(\mathrm{p}<0.05)$ in blood of the exposed fish when compared with the control as seen in Table 4, while that of the fish fed with vitamin E supplemented feed increased significantly when compared with those exposed to copper sulphate alone. There was no significant difference in the monocyte count across the groups.

Acute exposure to copper sulphate also affected the erythrocyte osmotic resistance in hypotonic solution as seen in Fig. 2. For example, at $0 \% \mathrm{NaCl}$ concentration, the erythrocyte osmotic fragility of the fish in group $\mathrm{C}$ that was exposed to copper sulphate $(20 \mathrm{mg} / \mathrm{L})$ alone was significantly higher $(\mathrm{p}<0.05)$ than that of group $\mathrm{F}$ that was exposed to copper sulphate $(5 \mathrm{mg} / \mathrm{L})$ plus vitamin Esupplemented feed. At $0.5 \% \mathrm{NaCl}$ concentration, the fish in group $\mathrm{C}$ had significantly lower $(\mathrm{p}<0.05)$ erythrocyte osmotic fragility compared to the fish in groups $\mathrm{A}, \mathrm{D}, \mathrm{E}$ and F. Furthermore, at $0.7 \% \mathrm{NaCl}$ concentration, the erythrocyte osmotic fragility of groups D and $\mathrm{F}$ was significantly higher $(\mathrm{p}<0.05)$ than the fish in group $\mathrm{C}$.

TABLE 3: EFFECT OF COPPER SULPHATE ON ERYTHROCYTE PARAMETERS OF AFRICAN CATFISH (CLARIAS GARIEPINUS) AS MODULATED BY VITAMIN E

\begin{tabular}{ccccccc}
\hline Parameters & $\mathbf{A}$ & $\mathbf{B}$ & $\mathbf{C}$ & $\mathbf{D}$ & $\mathbf{E}$ \\
\hline $\mathrm{PCV}(\%)$ & $47.20 \pm 8.08^{\mathbf{a}}$ & $43.40 \pm 3.85^{\mathbf{b}}$ & $30.20 \pm 5.81^{\text {abcd }}$ & $39.00 \pm 2.24$ & $46.00 \pm 3.32^{\mathbf{c}}$ & $40.00 \pm 4.53^{\mathbf{d}}$ \\
$\mathrm{Hb}(\mathrm{g} / \mathrm{dl})$ & $10.80 \pm 1.66^{\mathbf{a}}$ & $10.38 \pm 1.50^{\mathbf{b}}$ & $7.66 \pm 1.44^{\text {abc }}$ & $9.34 \pm 1.61$ & $10.44 \pm 0.85^{\mathbf{c}}$ & $9.25 \pm 0.35$ \\
$\mathrm{Rbc}\left(\mathrm{x} 10^{6} / \mu \mathrm{L}\right)$ & $3.55 \pm 0.38^{\text {ad }}$ & $3.61 \pm 0.35^{\mathbf{b e}}$ & $2.28 \pm 0.22^{\text {abc }}$ & $2.21 \pm 0.20^{\text {def }}$ & $3.44 \pm 0.78^{\mathbf{c f}^{\mathbf{b}}}$ & $3.01 \pm 0.40$ \\
$\mathrm{MCV}$ & $236.74 \pm 37.19^{\text {ae }}$ & $268.40 \pm 19.51^{\text {bf }}$ & $133.20 \pm 27.56^{\text {abcd }}$ & $177.60 \pm 20.39^{\text {ef }}$ & $212.84 \pm 30.40^{\mathbf{c}}$ & $227.73 \pm 32.11^{\mathbf{d}}$ \\
$\mathrm{MCH}$ & $45.60 \pm 10.21$ & $41.46 \pm 9.72$ & $33.87 \pm 6.94$ & $42.88 \pm 10.73$ & $29.46 \pm 4.08$ & $46.74 \pm 17.95$ \\
$\mathrm{MCHC}$ & $25.64 \pm 2.11^{\mathbf{a}}$ & $25.04 \pm 1.77^{\text {bd }}$ & $20.65 \pm 1.92^{\text {abcd }}$ & $21.84 \pm 1.41$ & $24.12 \pm 2.09$ & $24.33 \pm 1.78^{\mathbf{c}}$ \\
\hline
\end{tabular}

Values are presented as mean $\pm \mathrm{SD}$ while values with the same superscript alphabets along the same row are significantly different at $\mathrm{P}<0.05$. $\mathrm{A}=\mathrm{Control}$, $\mathrm{B}=$ Vitamin E-supplemented feed, $\mathrm{C}=$ Copper sulphate $(20 \mathrm{mg} / \mathrm{L})$ alone, $\mathrm{D}=$ Copper sulphate $(5 \mathrm{mg} / \mathrm{L})$ alone, $\mathrm{E}=\mathrm{Copper}$ sulphate $(20 \mathrm{mg} / \mathrm{L})$ alone + Vitamin E-supplemented feed, $\mathrm{F}=$ Copper sulphate $(5 \mathrm{mg} / \mathrm{L})$ alone + Vitamin E-supplemented feed, $\mathrm{n}=$ number of fish

TABLE 4: EFFECT OF COPPER SULPHATE ON ERYTHROCYTE PARAMETERS OF AFRICAN CATFISH (CLARIAS GARIEPINUS) AS MODULATED BY VITAMIN E

\begin{tabular}{|c|c|c|c|c|c|c|}
\hline Parameters & $\mathbf{A}$ & B & $\mathbf{C}$ & D & $\mathbf{E}$ & $\mathbf{F}$ \\
\hline TWBC $\left(\times 10^{6} / \mu \mathrm{L}\right)$ & $1.20 \pm 0.07^{\mathrm{ab}}$ & $1.23 \pm .01^{\mathrm{cd}}$ & $0.40 \pm 0.09^{\text {acefg }}$ & $0.90 \pm 0.09^{\text {bdehi }}$ & $1.22 \pm 0.15^{\mathrm{chh}}$ & $1.30 \pm 0.14^{\text {dgi }}$ \\
\hline Lymph. $(/ \mu \mathrm{l})$ & $657.00 \pm 84.16^{\mathbf{a}}$ & $782.80 \pm 40.31^{\text {be }}$ & $309.00 \pm 66.34^{\text {abcd }}$ & $484.80 \pm 120.60^{\text {ef }}$ & $787.50 \pm 157.60^{\text {cf }}$ & $596.00 \pm 168.60^{d}$ \\
\hline$(\%)$ & $(79.40 \pm 5.18)$ & $(78.60 \pm 6.54)$ & $(80.00 \pm 5.10)$ & $(74.00 \pm 9.87)$ & $(70.80 \pm 2.17)$ & $(48.40 \pm 5.23)$ \\
\hline Neut. $\quad(/ \mu 1)$ & $109.20 \pm 12.10^{\mathrm{a}}$ & $125.80 \pm 13.25^{\mathrm{bcd}}$ & $62.30 \pm 9.50^{\text {abef }}$ & $83.40 \pm 15.86^{\mathrm{c}}$ & $96.60 \pm 17.23^{\mathrm{de}}$ & $104.80 \pm 18.10^{f}$ \\
\hline$(\%)$ & $(10.80 \pm 5.98)$ & $(15.60 \pm 6.73)$ & $(2.20 \pm 1.79)$ & $(16.80 \pm 9.52)$ & $(17.20 \pm 2.78)$ & $(41.80 \pm 7.53)$ \\
\hline Mono. $(/ \mu 1)$ & $91.50 \pm 12.48$ & $63.30 \pm 25.72$ & $84.70 \pm 11.89$ & $71.50 \pm 28.43$ & $120.60 \pm 50.39$ & $97.30 \pm 24.27$ \\
\hline$(\%)$ & $(9.80 \pm 2.86)$ & $(5.80 \pm 2.78)$ & $(17.80 \pm 5.02)$ & $(9.00 \pm 3.54)$ & $(12.00 \pm 2.55)$ & $(9.80 \pm 6.94)$ \\
\hline
\end{tabular}

Values are presented as mean $\pm \mathrm{SD}$ while values with the same superscript alphabets along the same row are significantly different at $\mathrm{P}<0.05$. $\mathrm{A}=\mathrm{Control}$, $\mathrm{B}=$ Vitamin E-supplemented feed, $\mathrm{C}=$ Copper sulphate $(20 \mathrm{mg} / \mathrm{L})$ alone, $\mathrm{D}=$ Copper sulphate $(5 \mathrm{mg} / \mathrm{L})$ alone, $\mathrm{E}=\mathrm{Copper}$ sulphate $(20 \mathrm{mg} / \mathrm{L})$ alone + Vitamin E-supplemented feed, F = Copper sulphate $(5 \mathrm{mg} / \mathrm{L})$ alone + Vitamin E-supplemented feed, $\mathrm{n}=$ number of fish, TWBC=Total white blood cells, Lymp $=$ Lymphocytes, Neut $=$ Neutrophils, Mono $=$ Monocytes .

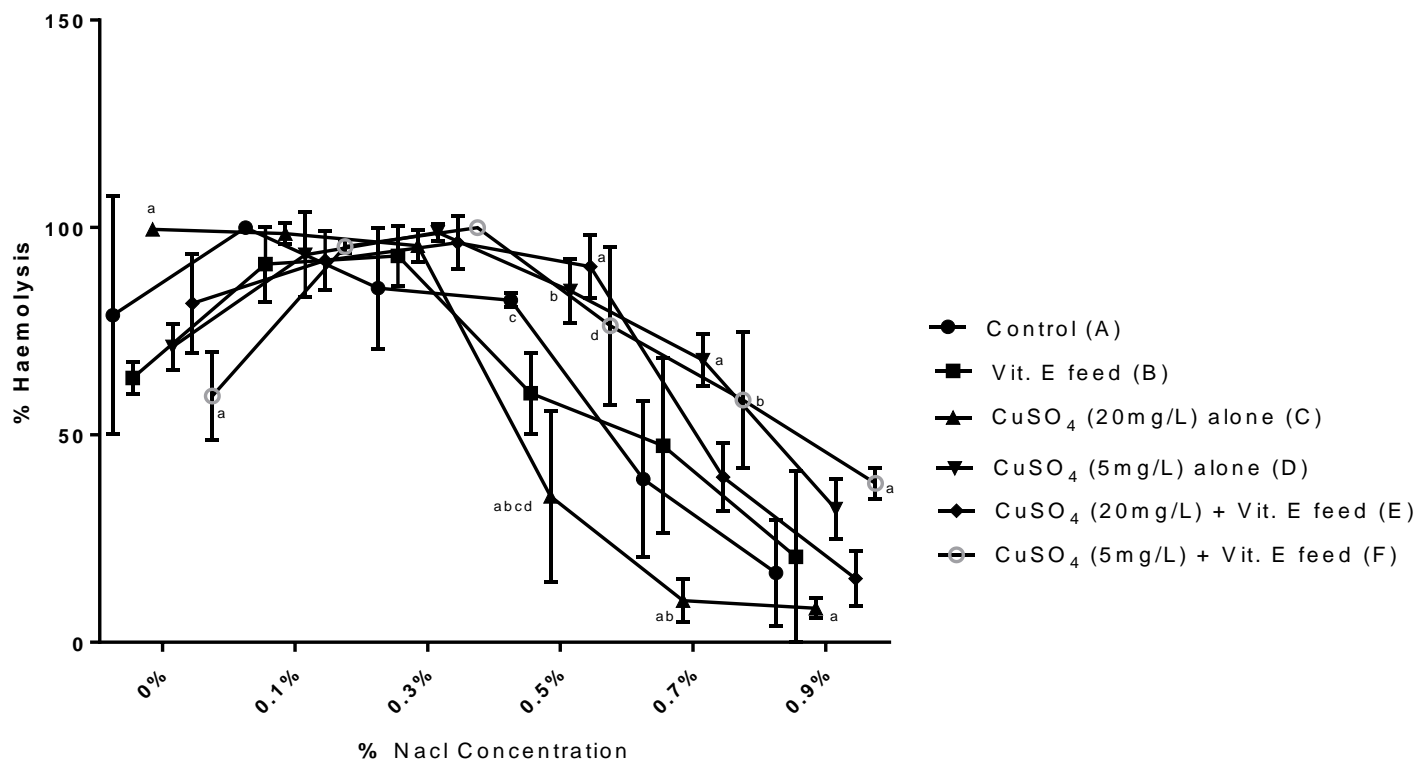

Fig. 2. Erythrocytes osmotic fragility of African catfish (Claria gariepinus) exposed to acute copper sulphate toxicity and concurrent treatment with vitamin $\mathrm{E}$. Values are expressed as mean $\pm \mathrm{SD}$ and $\mathrm{n}$ is 5 for each group. 


\section{Plasma biochemical parameters}

The effects of acute copper sulphate toxicity on plasma biochemical parameters in African catfish are presented in Table 5. The activity of aspartate transaminase (AST), alanine amino transferase (ALT) and alkaline phosphatase (ALP) increased significantly $(\mathrm{p}<0.05)$ in group $\mathrm{C}$ that was exposed to copper sulphate $(20 \mathrm{mg} / \mathrm{L})$ but this increase was mitigated/corrected in groups co-treated with vitamin-E. The urea and creatinine levels in the groups exposed to $20 \mathrm{mg} / \mathrm{L}$ and $5 \mathrm{mg} / \mathrm{L}$ of copper sulphate was significantly lower
$(\mathrm{P}<0.05)$ when compared with the control. The altered urea and creatinine levels were corrected in the groups co-treated with Vitamin-E. The plasma protein profile was altered as a result of copper sulphate exposure. The results showed a significant reduction $(\mathrm{p}<0.05)$ in total protein and globulin levels in the fish exposed to copper sulphate especially those exposed to $20 \mathrm{mg} / \mathrm{L}$ copper sulphate while albumin was insignificantly reduced. Co-treatment with copper sulphate and vitamin E-supplemented feed improved the plasma protein levels even better than the control values.

TABLE 5: EFFECTS OF ACUTE COPPER SULPHATE TOXICITY ON PLASMA BIOCHEMICAL PARAMETERS IN THE AFRICAN CATFISH (CLARIAS GARIEPINUS) AS MODULATED BY VITAMIN E

\begin{tabular}{|c|c|c|c|c|c|c|}
\hline Parameters & $\mathbf{A}$ & B & $\mathbf{C}$ & D & $\mathbf{E}$ & $\mathbf{F}$ \\
\hline AST (IU/L) & $12.64 \pm 2.00^{\mathrm{a}}$ & $12.33 \pm 1.79^{b}$ & $18.67 \pm 2.52^{\text {abcd }}$ & $13.33 \pm 1.53$ & $13.00 \pm 1.27^{\mathrm{c}}$ & $12.94 \pm 2.52^{\mathrm{d}}$ \\
\hline ALT (IU/L) & $9.33 \pm 1.53^{\mathrm{a}}$ & $8.47 \pm 1.24^{b}$ & $14.67 \pm 1.53^{\mathrm{abcd}}$ & $11.67 \pm 2.08$ & $8.33 \pm 1.53^{\mathrm{c}}$ & $9.33 \pm 2.08^{d}$ \\
\hline ALP(IU/L) & $42.67 \pm 3.64^{\mathrm{a}}$ & $40.67 \pm 3.07^{\mathbf{b}}$ & $55.11 \pm 4.00^{\mathrm{abc}}$ & $48.33 \pm 6.66$ & $44.33 \pm 3.43$ & $43.22 \pm 2.49^{c}$ \\
\hline Urea (mg/dl) & $26.67 \pm 3.06^{\mathrm{a}}$ & $27.67 \pm 3.51^{\mathrm{b}}$ & $18.67 \pm 1.53^{\mathrm{abcd}}$ & $23.33 \pm 1.53^{\mathrm{e}}$ & $30.33 \pm 2.52^{\mathrm{ce}}$ & $25.67 \pm 2.08^{d}$ \\
\hline Creatinine $(\mathrm{mg} / \mathrm{dl})$ & $0.87 \pm 0.12^{\mathrm{abc}}$ & $0.80 \pm 0.10^{\text {de }}$ & $0.43 \pm 0.06^{\text {adf }}$ & $0.53 \pm 0.06^{\text {be }}$ & $0.73 \pm 0.06^{\mathrm{f}}$ & $0.60 \pm 0.10^{\mathbf{c}}$ \\
\hline Plasma proteins $(\mathrm{g} / \mathrm{dl})$ & $6.77 \pm 0.18^{\mathrm{a}}$ & $6.87 \pm 0.25^{\mathrm{b}}$ & $6.03 \pm 0.21^{\mathrm{abcd}}$ & $6.57 \pm 0.31$ & $7.13 \pm 0.12^{\mathrm{c}}$ & $6.87 \pm 0.25^{\mathrm{d}}$ \\
\hline Albumin $(\mathrm{g} / \mathrm{dl})$ & $3.73 \pm 0.32$ & $3.90 \pm 0.27$ & $3.50 \pm 0.10$ & $3.73 \pm 0.31$ & $4.17 \pm 0.12$ & $3.80 \pm 0.30$ \\
\hline Globulin $(\mathrm{g} / \mathrm{dl})$ & $3.93 \pm 0.24 \mathrm{abc}$ & $3.97 \pm 0.12^{\text {def }}$ & $2.53 \pm 0.29^{\text {adgh }}$ & $3.01 \pm 0.12$ bei & $3.34 \pm 0.10^{\text {cfg }}$ & $3.57 \pm 0.14^{\mathrm{hi}}$ \\
\hline Total cholesterol (mg/dl) & $164.70 \pm 5.51$ & $155.00 \pm 7.94$ & $163.30 \pm 7.02$ & $158.70 \pm 11.93$ & $151.30 \pm 12.22$ & $171.00 \pm 12.53$ \\
\hline Triglycerides(mg/dl) & $70.00 \pm 12.53$ & $57.33 \pm 4.73$ & $72.67 \pm 12.58$ & $66.00 \pm 22.61$ & $57.33 \pm 15.50$ & $78.67 \pm 27.21$ \\
\hline HDL (mg/dl) & $44.67 \pm 2.89$ & $40.33 \pm 3.51$ & $45.00 \pm 4.00$ & $45.00 \pm 4.36$ & $41.33 \pm 5.51$ & $48.00 \pm 5.57$ \\
\hline $\mathrm{LDL}(\mathrm{mg} / \mathrm{dl})$ & $135.00 \pm 9.64$ & $120.70 \pm 10.50$ & $142.30 \pm 3.51$ & $136.30 \pm 12.01$ & $126.00 \pm 12.29$ & $147.70 \pm 15.57$ \\
\hline
\end{tabular}

Values are presented as mean $\pm \mathrm{SD}$ while values with the same superscript alphabets along the same row are significantly different at $\mathrm{P}<0.05$. A $=$ Control, B = Vitamin E-supplemented feed, C = Copper sulphate $(20 \mathrm{mg} / \mathrm{L})$ alone, $\mathrm{D}=$ Copper sulphate $(5 \mathrm{mg} / \mathrm{L})$ alone, E $=\mathrm{Copper}$ sulphate $(20 \mathrm{mg} / \mathrm{L})$ alone + Vitamin E-supplemented feed, $\mathrm{F}=$ Copper sulphate $(5 \mathrm{mg} / \mathrm{L})$ alone + Vitamin E-supplemented feed, $\mathrm{n}=$ number of fish

\section{E. Markers of oxidative stress}

The effects of acute copper sulphate toxicity on markers of oxidative stress in the gills (Fig. 2), liver (Fig. 3) and kidneys (Fig. 4) of African catfish and the modulatory effect of vitamin $\mathrm{E}$ are shown below. As shown in figure 3, the glutathione peroxidase (GPx), glutathione-S-transferase (GST) and reduced glutathione (GSH) of groups exposed to copper sulphate $(20 \mathrm{mg} / \mathrm{L}$ and $5 \mathrm{mg} / \mathrm{L})$ were significantly lower $(\mathrm{p}<0.05)$ than that of the control group. The hydrogen peroxide generation $\left(\mathrm{H}_{2} \mathrm{O}_{2}\right)$ and malondialdehyde (MDA) of the fish exposed to copper sulphate were significantly higher $(p<0.05)$ than that of the control group. Supplementation with vitamin $E$ restored the altered parameters close to the values obtained in the control group. Fig. 4 and 5 show the effect of acute copper sulphate toxicity on markers of oxidative stress in the liver and kidney of African catfish respectively and the modulatory effect of vitamin E. In the groups exposed to copper sulphate $(20 \mathrm{mg} / \mathrm{L}$ and $5 \mathrm{mg} / \mathrm{L})$, the activities of the enzymes GPx, GST and GSH were significantly lower $(\mathrm{p}<0.05)$, while the malondialdehyde and hydrogen peroxide generation were significantly higher $(p<0.05)$ than that of the control groups. In the liver, the total protein concentration was significantly lower $(\mathrm{p}<0.05)$ in the group exposed to $20 \mathrm{mg} / \mathrm{L}$ of copper sulphate than the control group and the group fed with vitamin Esupplemented feed, but there was no significant difference in the total protein level in the kidney. Supplementation with vitamin E increased the total protein level, GPx, GST and GSH activities while decreasing the hydrogen peroxide generation and lipid peroxidation better than the toxicant groups.

\section{DISCUSSION}

The study demonstrated the toxic effect of copper sulphate, which was evidenced by the significant reduction in the growth performance parameters (decrease in body weight, weight gain and feed conversion ratio (which is an indicator of feed efficiency) as seen in the fish exposed to different doses of copper sulphate only. The observed reduction in body weight was probably due to high energy demand and reduced feed consumption in fish exposed to toxic chemicals. For example, it was reported that exposure to toxicants results in reduced body weight due to reduced feed consumption [37]. In the present study, the growth parameters improved significantly in vitamin Esupplemented groups compared to control group. This is also in agreement with the report of Hossein et al., [38] who recorded an increase in growth parameters in vitamin Esupplemented capsian brown trout fish following exposure to different doses of vitamin $\mathrm{E}$ and $\mathrm{C}$.

Copper sulphate increased the relative liver weight when compared with the control. The elevation in the relative liver weight is thought to be due to reduced body weight caused by copper sulphate while the weight of the liver remained unchanged or hepatocellular hyperplasia and hypertrophy in response their exposure to the toxicant [39]. But in fish fed with vitamin $\mathrm{E}$, the relative liver weight was not affected. This was probably due to the activity of vitamin E, which is a biological antioxidant that could contribute to improved growth because of its ability to neutralize free radicals and reduce lipid peroxidation in the plasma, liver and muscles [40], [41]. It is generally accepted that apart from microbial spoilage, lipid oxidation is the primary process by which 
quality loss of muscle occurs in food animals, thereby resulting in weight loss [42].
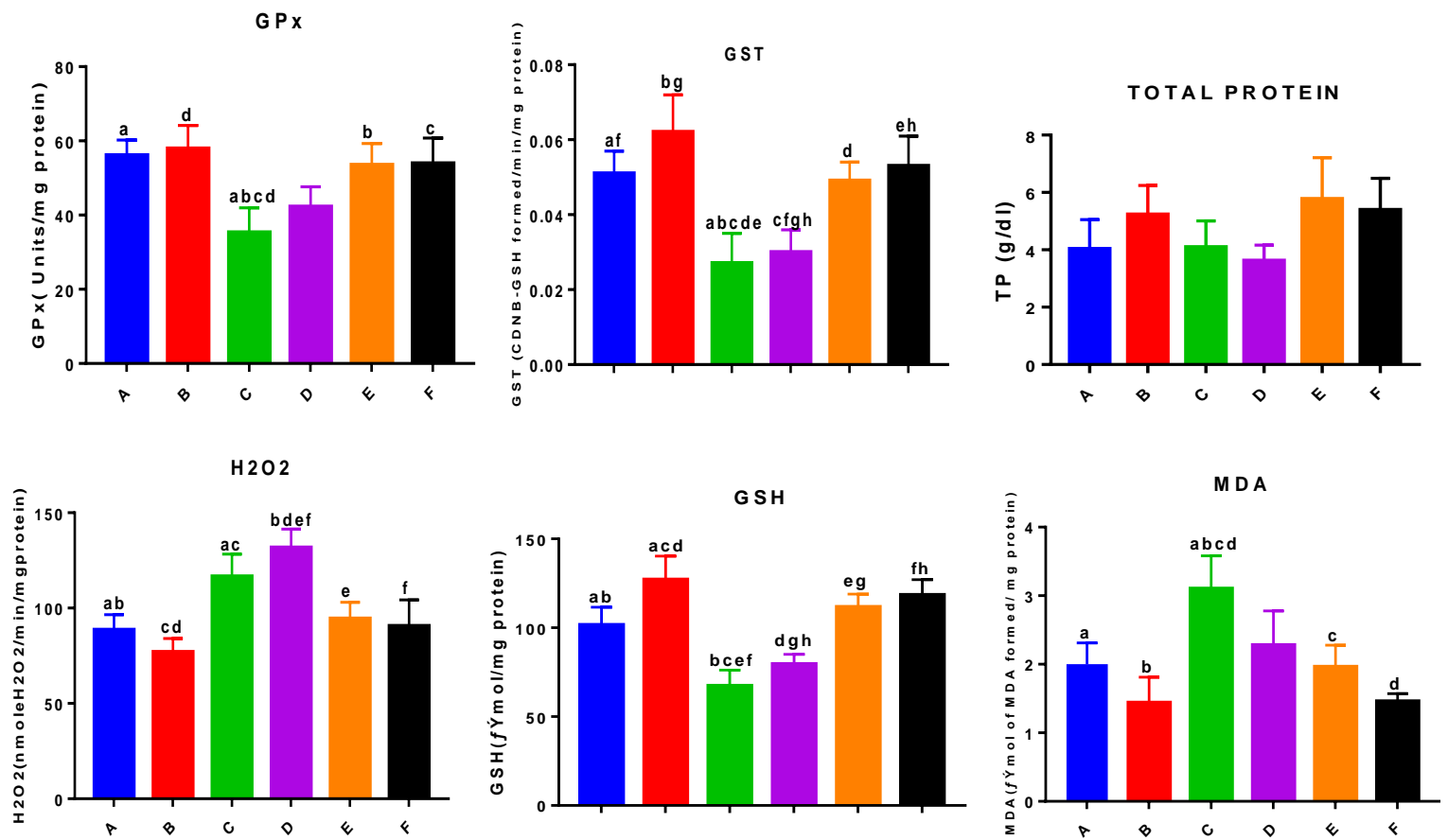

Fig. 3. Effect of acute copper sulphate toxicity on markers of oxidative stress in the gills of African catfish as modulated by vitamin $\mathrm{E}$. $\mathrm{A}=\mathrm{Control}, \mathrm{B}=$ Vitamin E-supplemented feed, $\mathrm{C}=$ Copper sulphate $(20 \mathrm{mg} / \mathrm{L})$ alone, $\mathrm{D}=$ Copper sulphate $(5 \mathrm{mg} / \mathrm{L})$ alone, $\mathrm{E}=\mathrm{Copper}$ sulphate $(20 \mathrm{mg} / \mathrm{L})$ alone $+\mathrm{Vitamin}$ E-supplemented feed, F = Copper sulphate $(5 \mathrm{mg} / \mathrm{L})$ alone + Vitamin E-supplemented feed. Values with the same superscript alphabets are significantly different at $\mathrm{p}<0.05$.
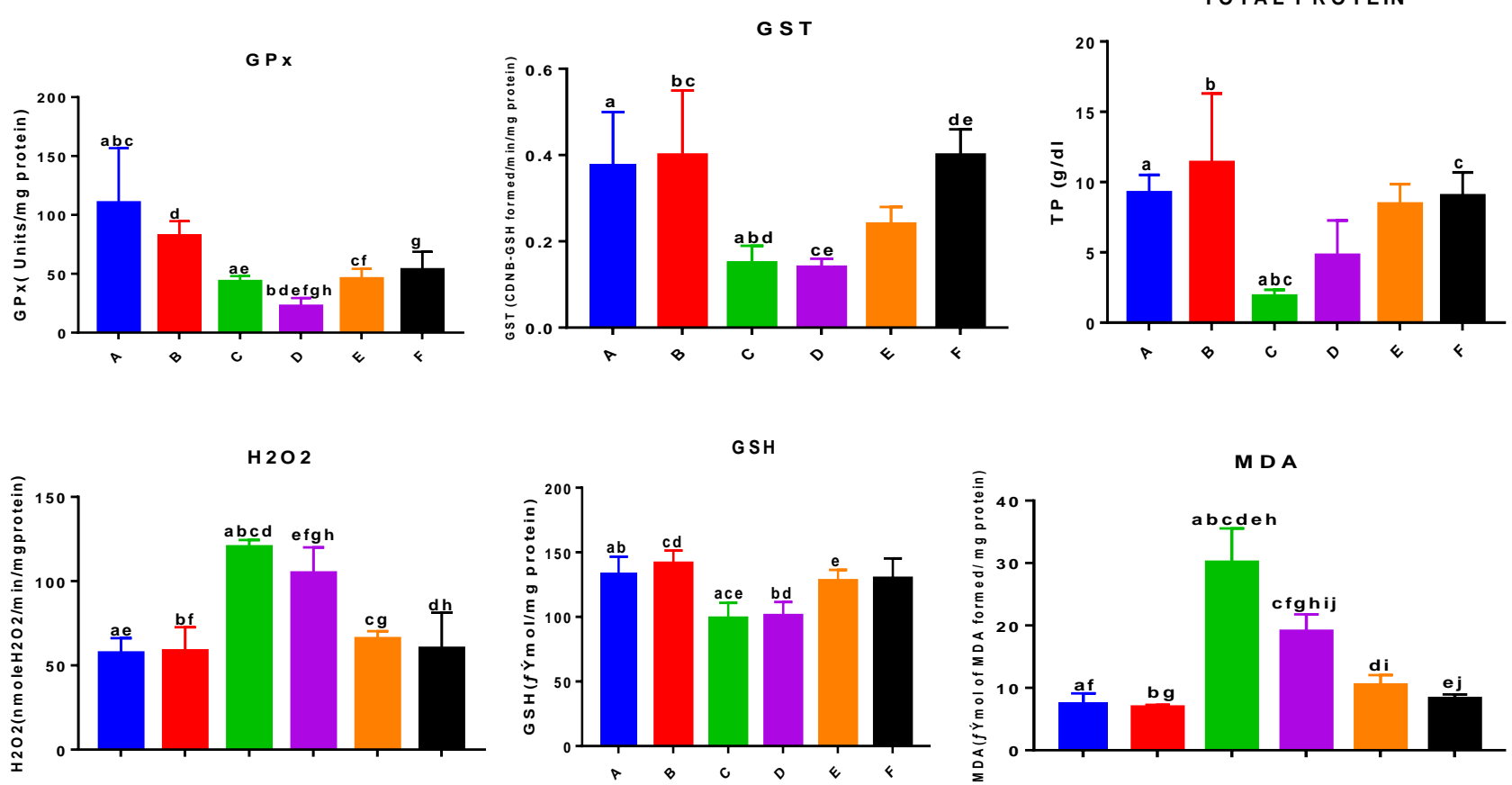

Fig. 4: Effect of acute copper sulphate toxicity on markers of oxidative stress in the liver of African catfish as modulated by vitamin $\mathrm{E}$. $\mathrm{A}=\mathrm{Control}, \mathrm{B}=$ Vitamin E-supplemented feed, C = Copper sulphate $(20 \mathrm{mg} / \mathrm{L})$ alone, $\mathrm{D}=$ Copper sulphate $(5 \mathrm{mg} / \mathrm{L})$ alone, E = Copper sulphate $(20 \mathrm{mg} / \mathrm{L})$ alone + Vitamin E-supplemented feed, $\mathrm{F}=$ Copper sulphate $(5 \mathrm{mg} / \mathrm{L})$ alone + Vitamin E-supplemented feed.Values with the same superscript alphabets are significantly different at $\mathrm{p}<0.05$. 

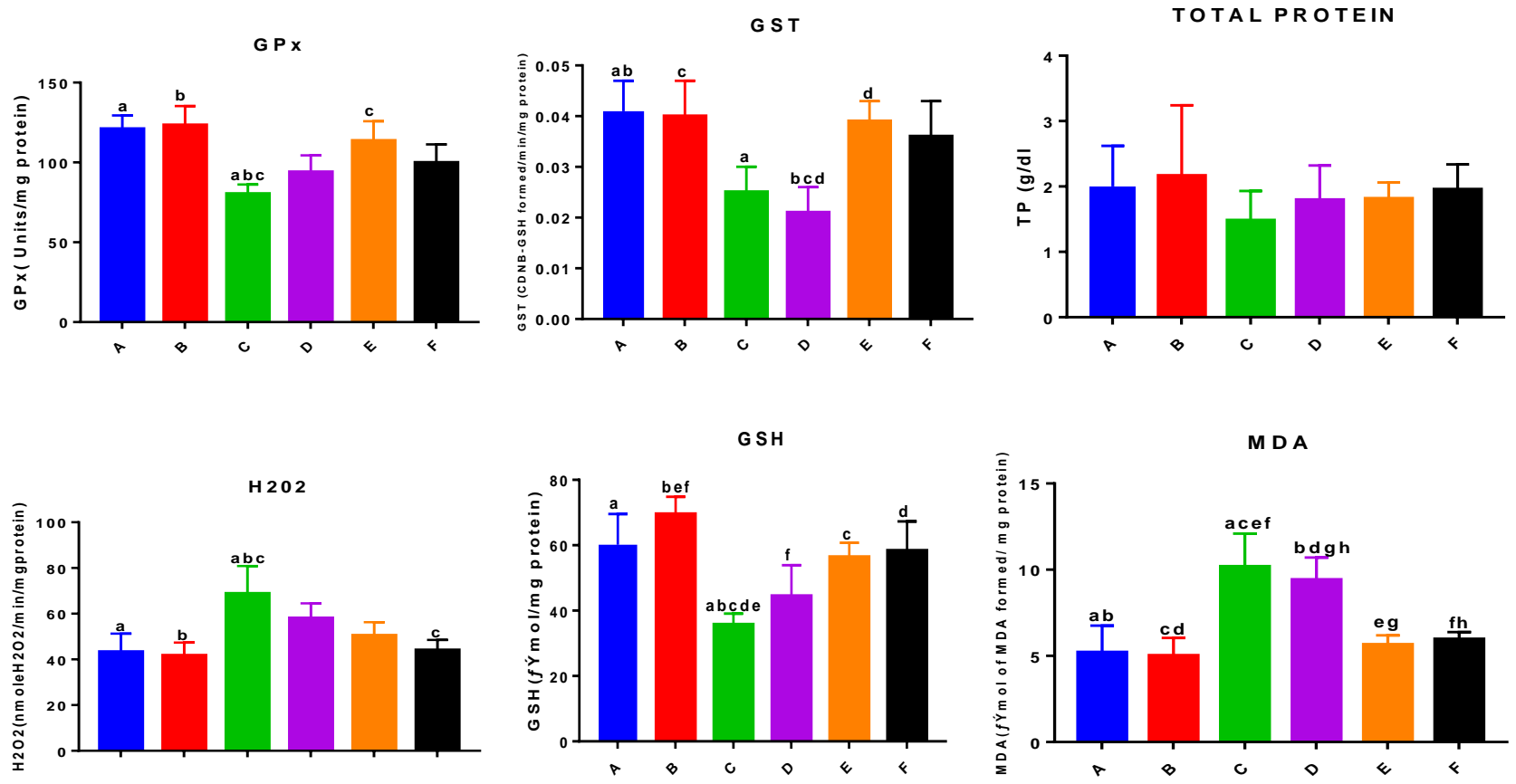

Fig. 5: Effect of acute copper sulphate toxicity on markers of oxidative stress in the kidney of African catfish as modulated by vitamin E. A $=$ Control, B = Vitamin E-supplemented feed, $\mathrm{C}=$ Copper sulphate $(20 \mathrm{mg} / \mathrm{L})$ alone, $\mathrm{D}=$ Copper sulphate $(5 \mathrm{mg} / \mathrm{L})$ alone, $\mathrm{E}=\mathrm{Copper}$ sulphate $(20 \mathrm{mg} / \mathrm{L})$ alone + Vitamin E-supplemented feed, $\mathrm{F}=$ Copper sulphate $(5 \mathrm{mg} / \mathrm{L})$ alone + Vitamin E-supplemented feed. Values with the same superscript alphabets are significantly different at $\mathrm{p}<0.05$.

Haematological profile has been known to be a good indicator of the physiological variations after exposure to pollutants and other pathophysiological conditions, reflecting the overall health status of fish [43]. In the current study, acute exposure of African catfish to copper sulphate resulted in microcytic hypochromic anaemia as evidenced by a significant decrease in the PCV, RBC, haemoglobin, $\mathrm{MCV}$ and $\mathrm{MCHC}$ values which were corrected by vitamin E. The decrease in PCV, RBC and haemoglobin values indicate deterioration of the condition of the fish and development of anaemia. These reductions after exposure to pollutants may be attributed to the inhibition of erythropoiesis or an increased rate of erythrocyte destruction in the blood or in haematopoietic organs [44]. Haemoglobin concentration reveals the status of an organism's oxygen carrying capacity and the organism itself tries to maintain them as much as possible in the face of any stressor. Reduction of haemoglobin affects the oxygen carrying capacity [45] and poses a serious challenge to the survival of fish in aquatic environment [46]-[48]. The reduced haematological parameters were corrected in the fish fed with vitamin E-supplemented feed. The enhancing action of vitamin $\mathrm{E}$ on fish haematology has been attributed to its role as antioxidant protecting cell membranes including red blood cells against oxidative damages [49].

Erythrocyte osmotic fragility reveals the tendency of erythrocytes to haemolyse or rupture under stress and is affected by several factors including membrane composition and integrity as well as cells' sizes and surface area to volume ratio [50]. Due to the damaging effects of free radicals and reactive oxygen species on erythrocyte membrane proteins and lipids resulting in increased fluidity and susceptibility to osmotic lysis, erythrocyte osmotic fragility has been used as a marker of oxidative stress induced by several factors such as aging [24], exercise [51], transportation stress [52] and haemodialysis [53]. In the present study, exposure to copper sulphate led to an increase in erythrocytes osmotic fragility except for the fish exposed to sub-lethal dose of copper sulphate $(20 \mathrm{mg} / \mathrm{L})$ that had very low erythrocytes osmotic fragility. These low erythrocytes osmotic fragility could be attributed to bone marrow response to anaemia leading to the release of large amount of reticulocytes, which are more osmotically stable into circulation. According to Robert [54], reticulocytes are immature anucleated red cells containing blue-stained granules which are more resistant to osmotic lysis due to the presence of mitochondria which pumps water out of the cell.

Exposure to copper sulphate resulted in leukopenia due to reduction in leucocyte values in the exposed fish. The decreased number of white blood cells (leukopenia) may be due to generalized injury caused to the haematopoietic stem cells in the bone marrow and other erythropoietic organs by exposure to heavy metals [55]. Similar disruption in haemopoietic mechanisms was observed by Adjroud [56] after potassium dichromate exposure in both male and female rats. This was corrected in the fish fed with vitamin E-containing feed where the leucocyte values were elevated. This activity of vitamin E may not be unconnected with its antioxidant effect and its role as a free radical scavenger. Vitamin E play a vital role in scavenging lipid peroxyl radical [57] and maintenance of fish immunity [58]. Vitamin $\mathrm{E}$ has also been considered as an activator of phagocyte population and immunostimulants [16].

Plasma biochemical parameters such as urea and creatinine are biomarkers for liver and kidney function and serve as useful indicators of stress impacts caused by pollutants [59]. In the present study, urea and creatinine levels were observed to be significantly lower in the fish exposed to copper sulphate when compared to the control. This could be as a result of liver damage because these 
metabolites are produced in the liver and low levels indicate that the liver was probably unable to make the normal amount of these metabolites [60].

Plasma enzymes, AST, ALT and ALP are found in several fish tissues, such as heart, kidneys, liver, brain, erythrocyte, intestine and gills. More specifically, AST and ALT enzyme activities are predominant in the liver and the cardiac tissues; therefore alterations in their activities could indicate liver injury and cardiotoxicity [61]. Increased AST, ALT and ALP activity has also been observed in liver and kidney impairment and during exposure to toxic metals and xenobiotics [62]. Therefore, the release of these intracellular enzymes into the bloodstream and their increased activity in plasma are important biomarkers for cell impairment or degenerative changes [63]. Enzymes such as ALT and AST, localized within the cells of numerous organs, including the liver, act as significant indicators for evaluation of organ status in cases of injury, tissue damage or organ dysfunction [64]. Accordingly, the results presented in the present study indicate significant increases in AST, ALT and ALP activities in fish exposed to copper sulphate when compared with the control while concomitant exposure to vitamin $\mathrm{E}$ led to significant decreases in ALT, AST and ALP levels, indicating protection from liver damage by vitamin E. Increase in these liver enzymes was similar to the observations of Zaghloul et al. [65] who exposed three species of fish, namely Oreochromis niloticus, Tilapia zillii, and Clarias gariepinus to copper metal for 30 days and recorded a significant increase in the levels of ALP, AST, and ALT enzymes. He attributed the elevated liver enzymes to liver damage by the heavy metal as a result of major pathologic changes in permeability of cell membrane or hepatic cell rupture.

The present investigation showed a significant decrease in the plasma total protein level (hypoproteinemia) after exposure to copper sulphate. Such decrease of total protein may be due to destruction of protein synthesizing subcellular structures, inhibition of hepatic synthesis of plasma protein as a result of liver cell damage, heavy metals-protein interaction or protein catabolism to provide extra energy requirement to overcome the stress in the polluted medium [66].

It is interesting to note that oxidative stress is a major hallmark of the findings on enzymatic and non-enzymatic antioxidant activities in the gills, liver and kidney of African catfish in the present study. Our findings showed that the reduced glutathione (GSH), Glutathione peroxidase (GPx) and Glutathione-S-Transferase activities in the gills, liver and kidney of African catfish exposed to copper sulphate were significantly lower when compared to those fed with vitamin E-supplemented feed. The reduction could be due to the exhaustion of these antioxidants as a result of the increased production of free radicals. The inhibition of the GPx activity by pesticides and copper sulphate has been reported in various studies in fish species including that of Yonar et al. [67] who reported that GPx activity in liver and gill of rainbow trout was decreased in copper sulphateinduced groups. Sayeed et al. [68] also reported that the exposure to deltamethrin caused a significant decrease in the activity of GPx in Channa punctatus gills. The reduced GST activity was in conformation with the work of Arojojoye et al., [69] who observed a lowered GST activity in African catfish exposed to heavy metals while reduction in the GSH content was also in agreement with the work of Heba [70] after the exposure of female catfish to endosulfan. Supplementation with vitamin E showed a significant improvement in the concentrations of these antioxidants in the gills, liver and kidneys of the exposed fish.

Total protein also used as oxidative stress biomarker was reduced in the gills and liver with the reduction more pronounced in the liver of those exposed to copper sulphate $(20 \mathrm{mg} / \mathrm{L})$. This reduction indicates the destructive effect of copper sulphate due to an increase in the generation of reactive oxygen species. This effect was mitigated in the group fed with vitamin E-supplemented feed.

Copper sulphate exposure also led to a significant increase in lipid peroxidation (MDA) and hydrogen peroxide generation in the gills, livers and kidneys of exposed fish. The increase in MDA levels in this study is in line with the work of Yonar et al. [67] who observed an increase in MDA levels in rainbow trout exposed to copper sulphate. The level of lipid peroxidation and hydrogen peroxide generation was significantly decreased in copper sulphate-exposed fish fed diets supplemented with vitamin E.

\section{CONCLUSION}

Copper sulphate, although used, as algaecide in aquaculture and agriculture is toxic to fish via increased oxidative stress as a result of generation of free radicals and other ROS and depletion of antioxidant defence. The results obtained in this study revealed that oxidative stress may, in part, be contributing to the copper sulphate-induced hepatic, renal and gill damage while dietary supplementation with vitamin $\mathrm{E}$ conferred protective effects against its toxicity. After exposure to this algaecide, the ability of vitamin $E$ to improve and recover the haematological and biochemical parameters as well as protection against reactive oxygen species were clearly seen in the fish fed with vitamin Esupplemented diet. As a result, vitamin E modulates and diminishes the adverse effects of copper sulphate toxicity thereby improving their physiological status and in turn raising their resistance to oxidative stress. Thus, the use of vitamin $\mathrm{E}$ in diet could safely be recommended whenever the use of copper sulphate for therapeutics is inevitable in fish.

\section{ACKNOWLEDGMENT}

The authors would like to acknowledge Dr Selim Alarape for his advice, Dr Kemi Fagbohun for providing the fish containers and members of Cardiorenal Research Group for providing assistance in determination of markers of oxidative stress.

\section{REFERENCES}

[1] F. Özkan, S. Gündüz, M. Berköz, and A. Hunt, "Induction of micronuclei and other nuclear abnormalities in peripheral erythrocytes of Nile tilapia, Oreochromis niloticus, following exposure to sublethal cadmium doses," Turk. J. Zool., 35(4): 585592, 2011.

[2] E. A. M. Shokr, "Effect of zinc on hematology and biochemistry of Nile Tilapia," J. Chem. Pharm. Res., 7(3):1943-1950, 2015. 
[3] I. Zarei, A. Pourkhabbaz, H. Alipour, and S. H. Khazaei, “Acute toxicity and the effects of copper sulphate $(\mathrm{CuSO} 4.5 \mathrm{H} 2 \mathrm{O})$ on the behavior of the black fish (Capoeta Fusca)," Iran. J. Toxicol., 6 (19): 771-778, 2013.

[4] A. A. McNevin, and C. E. Boyd, "Copper concentrations in Channel Catfish Ictalurus punctatus ponds treated with copper sulfate,' Journal of the World Aquaculture Society, 35(1), 16-24, 2004.

[5] C. A. Aguilar, C. Montalvo, and L. Rodríguez, "American oyster (Crassostrea virginica) and sediments as a coastal zone pollution monitor by heavy metals," Int J Environ Sci Technol., 9:579-586, 2012.

[6] M. K. Sabullah, S. A. Ahmad, and M. Y. Shukor, "Heavy metal biomarker: fish behavior, cellular alteration, enzymatic reaction and proteomics approaches," Int Food Res J., 22:435-454, 2015.

[7] J. Monisha, T. Tenzin, A. Naresh, B. M. Blessy, and N. B. Krishnamurthy, "Toxicity, mechanism and health effects of some heavy metals," Interdisciplinary Toxicology. 7(2):60-72, 2014.

[8] L. Jarup, Hazards of heavy metal contamination. British Medical Bulletin; 68(1):167-182, 2003.

[9] A. J. Calomeni, C. M. Kinley, T. D. Geer, K. J. Iwinski, M. Hendrikse, and J. H. Rodgers, "Relationship among aqueous copper half-lives and responses of Pimephales promelas to a series of copper sulphate pentahydrate concentrations," Ecotoxicology, 27(3), 278-285, 2018

[10] C. E. Boyd, and A. A. McNevin, Aquaculture, resource use, and the environment. Hoboken, NJ: John Wiley \& Sons, 2015; City and country as well as page used.

[11] J. D. Bowker, J. T. Trushenski, M. P. Gaikowski, and D. L. Straus, (Eds.). Guide to using drugs, biologics, and other chemicals in aquaculture. American Fisheries Society - Fish Culture Section 2014; Retrieved from https://www.fws.gov/ fisheries/aadap/PDF/guidetousingdrugs.pdf

[12] E. Y. Min, S. K. Baeck, and J. C. Kang, "Combined Effects of Copper and Temperature on Antioxidant Enzymes in the Black Rockfish Sebastes schlegeli. Fish," Aquat Sci. 17, 345, 2014.

[13] S. M. Picon-Camacho, M. Marcus-Lopez, J. E. Bron, and A. P. Shinn, "An assessment of the use of drug and non-drug interventions in the treatment of Ichthyophthirius miltifiliis Fouquet, 1876, protozoan parasite of freshwater fish," Parasitology, 139(2), 149190, 2012.

[14] United States Environmental Protection Agency. "Registration eligibility decision (RED) for coppers. 2009; (http://www.epa.gov/oppsrrd1/registration/RED/copper_red_ammen d.pdf).

[15] R. Brigelius-Flohé, and M. G. Traber, "Vitamin E functions and metabolism," Faseb Journal, 13 (10):1145-55, 1999.

[16] J. Eo, and K. J. Lee, "Effect of dietary ascorbic acid on growth and non-specific immune responses of tiger puffer, Takifugu rubripes. Fish Shellfish," Immunol. 25:611-616, 2008.

17] M. Pazos, A. Lourdes Sánchez, and I. Medina, "Alpha-tocopherol oxidation in fish muscle during chilling and frozen storage," Journal of Agriculture and Food Chemistry, 53, 4000-4005, 2005.

[18] F. D. Wilhelm, "Reactive oxygen species, antioxidants and fish mitochondria," Frontiers in Bioscience, 12, 1229-1237, 2007.

[19] X. Wang, and P. Quinn, "Vitamin E and its Function in Membranes," Prog. Lipid Res., 38, 309-336, 1999.

[20] A. E. Sayed, and H. A. M. Soliman, "Modulatory effects of green tea extract against the hepatotoxic effects of 4-nonylphenol in catfish (Clarias gariepinus)," Ecotoxicology and Environmental Safety, 149, 159-165, 2018

[21] I. A. Mekkawy, U. M. Mahmoud, M. N. Hana, and A. H. Sayed, "Cytotoxic and hemotoxic effects of silver nanoparticles on the African Catfish, Clarias gariepinus," (Burchell, 1822) Ecotoxicology and Environmental Safety 171.Microbiol. 64, 471-497, 2019.

22] A. W. Adil, M. Junaid and S. M. Zuber, "Determination of lethal toxicity of copper to Clarias gariepinus," International Journal of Advance Research in Science and Engineering. 2018; Volume No. 07, Special Issue No. 04.

[23] N. C. Jain, Schalm's Veterinary Haematology. 4th Edn., 1986; Lea and Febiger, Philadelphia.

[24] O. Azeez, F. Olayemi, J. and Olanrewaju, "Age and sex influences on the Haematology and Erythrocyte Osmotic Fragility of the Nigerian Turkey," Research Journal of Veterinary Sciences, 4(2), $43-49,2011$

[25] T. Kuribayashi, K. Sato, T. Joh, and M. Kaneoke, "Breeding of a non-urea-producing sake yeast carrying a FAS2 mutation," Myosciences, 58(4), 302-306, 2017.

[26] J. A. Onuegbu, K. A. Ubuo, K. M. Nnamdi, E. A. Joseph, L. A Gladys, E. O. Christian, M. O. Japhet, E. O. John, E. D. Chudi, and C. M. Samuel "Evaluation of nephrotoxic effect of lead exposure among automobile repairers in Nnewi Metropolis," Int J of Res Med Sci. 2(3):1107-1111, 2014

[27] M. M. Bradford, "A rapid and sensitive method for the quantitation of microgram quantities of protein utilizing the principle of proteindye binding." Anal Biochem., 72: 248-254, 1976.

[28] B. T. Doumas, W. A. Waston, and A. G. Biggs, "Biuret method for quantitative estimation of total protein in serum or plasma," Clin Chim Acta; 31: 87-91, 1971.

[29] M. Bilal, S. Freed, M. Z. Ashraf, and M. B. Khan, "Activity of acetylcholinesterase and acid and alkaline phosphatases in different insecticide treated Helicoverpa armigera (Hubner)," Environmental Science and Pollution research, 25(23), 22903-22910, 2018.

[30] T. H. Mallhi, M. I. Qadir, and Y. H. Khan, "Determination of phytoconstituents of $\mathrm{n}$-hexane extract of leaves of Morus nigra and elevation of their effects on biochemical and histopathological parameters in paracetamol intoxicated mice liver," Brazilian Journal of Pharmaceutical Sciences, 54(3), 1-5, 2018.

[31] E. O. Farombi, J. G. Tahnteng, A. O. Agboola, J. O. Nwankwo, and G. O. Emerole, "Chemoprevention of 2-acetylaminofluoreneinduced hepatotoxicity and lipid peroxidation in rats by kolaviron-a garcinia kola seed extract," Food Chem Toxicol., 38:353-541, 2000.

[32] D. J. Jollow, J. R. Michell, N. Zampaglione, and J. R. Gillete, "Bromobenzene induced liver necrosis: protective role of GSH and evidence for 3,4- bromobenzene oxide as the hepatotoxic metabolite," Pharm 11:151-169, 1974.

[33] E. O. Farombi, Y. P. Ajimoko, and O. A. Adelowo, "Effect of butachlor on antioxidant enzyme status and lipid peroxidation in fresh water African catfish, (Clarias gariepinus)," Int. J. Environ Res. Public Health, 5:423-427, 2008.

[34] S. F. Wolff, "Ferrous ion oxidation in the presence of ferric ion indicator xylenol orange for measurement of hydrogen peroxides,' Methods Enzymol. 233, 182-189, 1994.

[35] T. O. Omobowale, A. O. Ademola, R. A. Ebunoluwa, O. A. Abiola, O. A. Temitayo, M. I. Temitope, S. O. Blessing, A. A. Adeolu, and A. Y. Momoh, "Sodium Fluoride Induces Hypertension and Cardiac Complications through Generation of Reactive Oxygen Species and Activation of Nuclear Factor Kappa Beta," Environmental Toxicology, 2016; DOI 10.1002/tox.

[36] J. T. Rotruck, A. L. Pope, H. E. Ganther, A. B. Swanson, D. G. Hafeman, B. D. Hoekstra, J. M. Kumar, M. Kuncha, R. M. Borkar, R. Srinivas, and R. Sistla, "Baicalein alleviates doxorubicin induced cardiotoxicity via suppression of myocardial oxidative stress and apoptosis in mice," Life Sci. 144:8-18, 2016.

[37] K. Nieves-Puigdoller, B. T. Bjrnsson and S. D. McCormick, "Effects of hexazinone and atrazine on the physiology and endocrinology of smolt development in Atlantic salmon," Aquatic Toxicology, 84: 27 37, 2007.

[38] K. Hossein, S. Mahmoud, S. Mohammad, "Effects of $\alpha$-Tocopherol (vitamin E) and Ascorbic Acid (Vitamin C) and Their Combination on Growth, Survival and Some Haematological and Immunological Parameters of Caspian Brown Trout, Salmo Trutta Caspius juveniles," Turk. J. Fish. Aquat. Sci. 16: 385-393, 2016.

[39] R. R. Maronpot, K. Yoshizawa, A. Nyska, T. Harada, G. Flake, G. Mueller, B. Singh, and J. M. Ward, "Hepatic enzyme induction Histopathology," Toxicol Pathol., 38, 776-95, 2010.

[40] J. Gao, H. Lin, X. J. Wang, Z. G. Song, and H. C. Jiao, "Vitamin E supplementation alleviates the oxidative stress induced by dexamethasone treatment and improves meat quality in broiler chickens," Int. J. Poult. Sci. 89, 318-327, 2010.

[41] N. A. Selim, S. F. Youssef, A. F. Abdel-Salam, and S. A. Nada "Evaluations of some natural antioxidant sources in broiler diets: 1Effect on growth, physiological and immunological performance of broiler chicks," Int. J. Poult. Sci. 12, 561-571, 2013.

[42] D. J. Buckley, P. A. Morrissey, and J. I. Gray, "Influence of dietary vitamin E on the oxidative stability and quality of pig meat," $J$. Anim. Sci. 73, 3122-3130, 1995.

[43] A. S. A. Harabawy, and A. T. A. Ibrahim, "Sublethal toxicity of carbofuran pesticide on the African catfish Clarias gariepinus (Burchell, 1822): Hematological, biochemical and cytogenetic response," Ecotoxicol. Environ. Saf., 103: 61- 67, 2014.

[44] T. Vani, N. Saharan, S. C. Mukherjee, R. Ranjan, R. Kumar, and R. K. Brahmchari, "Deltamethrin induced alterations of hematological and biochemical parameters in fingerlings of Catla catla (Ham.) and their amelioration by dietary supplement of vitamin C," Pestic. Biochem. Physiol., 101: 16-20, 2011.

[45] V. S. Mini, "Haematological changes in a freshwater fish, Anabas testudineus (Bloch) on exposure to heavy metal toxicant Cadmium chloride," Asian Journal Of Science And Technologies, 6 (1): 988992, 2015. 
[46] B. Mallesh, P. K. Pandey, K. A. Kundan, and S. K. Vennila, "Bioconcentration of hexavalent chromium in Cirrhinus mrigala (Ham 1822) effect on haematological parameters," Journal of Earth Science, 5(1): 59-67, 2015.

[47] O. A. Akinrotimi, O. M. G. Abu, D. O. Bekbele, B. Udeme-Naa, and A. A. Aranyo, "Haematological characteristics of Tilapia guineensis from Buguma creek, Niger delta, Nigeria," Electronic J Environmental Agricultural and Food Chem., 9,1415-1422, 2010.

[48] U. U. Gabriel, S. N. Deekae, O. A. Akinrotimi, and O. O. Orokotan, "Haematological responses of Clarias gariepinus exposed to anaesthetics metomidate," Continent J Toxicol Res. 4, 18-29, 2011.

[49] P. K. Sahoo, and S. C. Mukherjee, "Influence of high dietary atocopherol acetate intakes on specific immune response, nonspecific resistance factors and disease resistance of healthy and Aflatoxin B1-induced immunocompromised Indian major Carp, Labeo rohita (Hamilton)," Aquaculture Nutrition, 8, 159-67, 2002.

[50] F. T. Fischbach, and M. B. Dunning, M. B. A manual of laboratory and diagnostic tests (8th ed.). Lippincott Williams \& Wilkins, 2008; p. 116.

[51] U. M. K. ȘEntuRk, F. GüNdüZ, O. Kuru, M. R. Aktekin, D. Kipmen, O. Z. YalçIn, M. Bor-küÇÜKatay, A. YeşIlkaya, and O. U. K. BaşKurt, "Exercise-induced oxidative stress affects erythrocytes in sedentary rats but not exercise trained rats, Journal of applied physiology, 91, 1999 - 2004, 2001.

[52] A. Adenkola, and J. Ayo, "Effect of road transportation on erythrocyte osmotic fragility of pigs administered ascorbic acid during the harmattan season in Zaria, Nigeria," Journal of cell and animal biology, 3, 004-008, 2009.

[53] F. Candan, and F. Gültekin, "Effect of vitamin C and zinc on osmotic fragility and lipid peroxidation in zinc deficient haemodialysis patients," Cell biochemistry and function, 20(1), 9598. 2002.

[54] V. P. Robert, Reticulocytes, their usefulness and measurement in peripheral blood. Clinics in Laboratory Medicine. 2002; Vol 22 (1).

[55] R. Shrivastava, S. Srivastava, R. K. Upreti, and U. C. Chaturvedi, "Effects of dengue virus infection on peripheral blood cells of mice exposed to hexavalent chromium with drinking water," Indian $\mathrm{J} \mathrm{Med}$ Res. 122(2):111-9, 2005.

[56] O. Adjroud, "Effects of potassium dichromate on haematological parameters in female and male wistar albino rats," Assiut Univ Bull Environ Res. 12(2):87-99, 2009.

[57] F. M. El-Demerdash, M. I. Yousef, F. S. Kedwany, and H. H. Baghdadi, "Cadmium-induced changes in lipid peroxidation, blood hematology, biochemical parameters and semen quality of male rats: protective role of vitamin E and $\beta$-carotene," Food Chem. Toxicol., 42: 1563-1571, 2004

[58] M. S. Hassaan, A. M. Goda, S. A. Mahmoud, and S. L. Tayel, "Protective effect of dietary vitamin E against fungicide copperoxychloride stress on Nile tilapia, Oreochromis niloticus (L.), fingerlings," Int. Aquat. Res., 6:1, 2014.

[59] U. M. Mahmoud, I. A. Mekkawy, and A. T. Ibrahim, "Biochemical Response of the AfricanCatfish, Clarias gariepinus (Burchell, 1822) to Sublethal Concentrations of Mercury Chloride with Supplementation of Selenium and Vitamin E," Toxicol. Environ. Health.Sci., 4(4): 218-234, 2012.

[60] S. C. Kalhan, Protein metabolism in pregnancy. Am J Clin Nutr; 2000; 71, 5 Suppl:1249S-55S

[61] O. Kori-Siakpere, R. B. Ikomi, and M. G. Ogbe, "Variations in acid phosphatase and alkaline phosphatase activities in the plasma of the African catfish: Clarias gariepinus exposed to sublethal concentrations of potassium permanganate," Asian. J. Exp. Biol. Sci. 1, 170-174, 2012.

[62] G. Atli, S. Y. Ariyurek, E. G. Kanak, and M. Canli, "Alterations in the serum biomarkers belonging to different metabolic systems of fish (Oreochromis niloticus) after $\mathrm{Cd}$ and $\mathrm{Pb}$ exposures," Environ. Toxicol. Pharmacol. 40, 508-515, 2015.

[63] M. Banaee, A. Sureda, A., Mirvaghefi, and K. Ahmadi, "Effects of diazinon on biochemical parameters of blood in rainbow trout," (Oncorhynchus mykiss). Pestic. Biochem. Phys. 99, 1-6, 2011.

[64] A. Louei-Monfared, and S. Soltani, "Effects of silver nanoparticles administration on the liver of rainbow trout (Oncorhynchus mykiss): histological and biochemical studies," Euro J Exp Bio., 3(2); 285 289, 2013.

[65] K. H. Zaghloul, W. A. Omar, and S. Abo-Hegab, "Toxicity specificity of copper in some freshwater fishes," Egypt. J. Zool., 47; 383-400, 2006.

[66] L. Fontana, E. Moreira, M. Torres, I. Ferna `ndez, A. Rios, F. Sanchez de Medina, and A. Gil, "Dietary nucleotides correct plasma and liver microsomal fatty acids alterations in rats with liver cirrhosis induced by oral intake of thioacetamide," $J$ Hepatol., 28:662-669, 1998.

[67] M. E. Yonar, U. Ispir, S. M. Yonar and M. Kirici, "Effect of copper sulphate on the antioxidant parameters in the rainbow trout fry, Oncorhynchus mykiss," - Cellular and Molecular Biology, 62: 55-58, 2016.

[68] I. Sayeed, S. Parvez, S. Pandey, B. Bin-Hafeez, R. Haque, and S. Raisuddin, "Oxidative stress biomarkers of exposure to deltamethrin in freshwater fish, Channa punctatus Bloch," Ecotoxicology and Environmental Safety, 56(2): 295-301, 2003

[69] O. A. Arojojoye, A. O. Ademola, and M. G. Ogundeyi, "Biomarkers of oxidative stress in Clarias gariepinus for assessing toxicological effects of heavy metal pollution of Abereke river in southwest Nigeria," Comparative Clinical Pathology. 2019; https://doi.org/10.1007/s00580-019-02999-8.

[70] S. H. Heba, (2015). "Vitamin E Attenuated the Oxidative Stress and Biochemical Changes Induced by Endosulfan in Female Catfish (Clarias gariepinus)," World J. Fish \& Marine Sci., 7 (4): 313-324, 2015, 2015. 